\title{
Reductive metabolism of the important atmospheric gas isoprene by homoacetogens
}

\author{
Miriam Kronen $^{1} \cdot$ Matthew Lee $\mathbb{D}^{1} \cdot$ Zackary L. Jones $^{1} \cdot$ Michael J. Manefield $^{1}$
}

Received: 7 May 2018 / Revised: 18 October 2018 / Accepted: 2 December 2018 / Published online: 14 January 2019

(c) The Author(s) 2019. This article is published with open access

\begin{abstract}
Isoprene is the most abundant biogenic volatile organic compound (BVOC) in the Earth's atmosphere and plays important roles in atmospheric chemistry. Despite this, little is known about microbiological processes serving as a terrestrial sink for isoprene. While aerobic isoprene degrading bacteria have been identified, there are no known anaerobic, isoprenemetabolizing organisms. In this study an $\mathrm{H}_{2}$-consuming homoacetogenic enrichment was shown to utilize $1.6 \mu$ moles isoprene $\mathrm{h}^{-1}$ as an electron acceptor in addition to $\mathrm{HCO}_{3}{ }^{-}$. The isoprene-reducing community was dominated by Acetobacterium spp. and isoprene was shown to be stoichiometrically reduced to three methylbutene isomers (2-methyl-1butene ( $>97 \%)$, 3-methyl-1-butene ( $\leq 2 \%), 2$-methyl-2-butene $(\leq 1 \%)$. In the presence of isoprene, $40 \%$ less acetate was formed suggesting that isoprene reduction is coupled to energy conservation in Acetobacterium spp. This study improves our understanding of linkages and feedbacks between biogeochemistry and terrestrial microbial activity.
\end{abstract}

\section{Introduction}

Ecosystems emit numerous biogenic volatile organic compounds (BVOCs), which affect atmospheric chemistry and therefore the Earth's climate [1-4]. By mass, between 30 and $50 \%$ of the estimated total global BVOC flux is isoprene (2-methyl-1,3-butadiene $\quad\left(\mathrm{CH}_{2}=\mathrm{C}\left(\mathrm{CH}_{3}\right)-\mathrm{CH}=\right.$ $\left.\mathrm{CH}_{2}\right)$ ), a highly volatile, unsaturated hydrocarbon $[5,6]$. An annual global terrestrial isoprene emission of $500-600 \mathrm{Tg}$ per year [7,8] and an oceanic emission of 0.1-1.2 Tg per year [9] has been estimated, which is similar in magnitude to methane sources at $526-569 \mathrm{Tg}$ per year [10]. The physiological role of isoprene in natural environments remains enigmatic [11]. It is mainly emitted by woody plants [12-15], though it is also released in the breath of

These authors contributed equally: Miriam Kronen, Matthew Lee

Supplementary information The online version of this article (https:// doi.org/10.1038/s41396-018-0338-z) contains supplementary material, which is available to authorized users.

Michael J. Manefield

manefield@unsw.edu.au

1 UNSW Water Research Centre, School of Civil and Environmental Engineering, UNSW Australia, Sydney, NSW 2052, Australia humans and other mammals [16, 17], marine algae [18], and by Gram-positive (e.g., Bacillus species) and Gramnegative bacteria (e.g., Escherichia coli, Pseudomonas fluorescens, various actinomycetes Pseudonocardia, Saccharomonospora, Streptomyces, Thermomonospora) [19-21].

In the atmosphere, isoprene reaction products modulate the oxidizing potential, which leads to a prolonged lifetime of greenhouse gases such as methane [12, 22-24]. Additionally, isoprene oxidation products cause secondary organic aerosols (SOA) formation [25], which affects the climate directly by scattering absorbance and indirectly via nuclei cloud formation [26, 27].

While sources of atmospheric isoprene have been wellstudied, terrestrial fates of isoprene remain relatively unexplored. Soils containing isoprene degrading microorganisms could serve as an important sink as shown by Cleveland and Yavitt [28]. They estimated the global soil isoprene sink at $20.4 \mathrm{Tg}$ per year, which is $4 \%$ of the estimated annual biogenic emission of isoprene [5]. Under aerobic conditions, most soil bacteria that have been shown to utilize isoprene as their sole carbon and energy source belong to the phylum Actinobacteria [28-31]. The most detailed biochemical characterization of an aerobic isoprene-metabolizing organism was conducted on Rhodococcus sp. strain AD45 [31-35]. These studies identified isoprene epoxide (1,2-epoxy-2-methyl-3-butene) and the 
two glutathione adducts, 1-hydroxy-2-glutathionyl-2methyl-3-butene (HGMB) and 2-glutathionyl-2-methyl-3butenoic acid (GMBA), as intermediates of isoprene oxidation [31-33]. Crombie et al. [34] published the whole genome of Rhodococcus sp. AD45 and identified additional genes involved in isoprene metabolism, though the complete pathway has not been resolved.

In the present study, the fate of isoprene in anoxic environments was investigated for the first time. Given the environmental abundance and ubiquity of isoprene, we hypothesized that it is available to anaerobic microorganisms. Samples taken from different environments were used to enrich for anaerobic isoprene utilizing microorganisms with the aim of determining the fate of isoprene in anaerobic microbial systems in order to better understand its global degradation pathways. We show for the first time that obligate anaerobes also transform isoprene. Moreover, whereas isoprene primarily serves as an electron donor in aerated soils, we provide evidence that is used as an electron acceptor to support homoacetogenesis.

\section{Materials and methods}

\section{Chemicals}

Isoprene $99 \%$ stock solution, 3-methyl-1-butene $\geq 99.0 \%$ (GC), 2-methyl-2-butene $\geq 99.0 \%$ (GC) and 2-methyl-1butene $\geq 99.5 \%$ (GC), ethylene $99.9 \%$ in steel cylinder were all purchased from Sigma-Aldrich, Castle Hill, Australia. Helium (>99.9999\% purity), nitrogen gas (>99.99\% purity), and air (zero grade purity) were purchased from BOC Gas, Australia. $\mathrm{H}_{2}$ (>99.99995\% purity) was obtained from a $\mathrm{H}_{2}$ generator (Parker domnick hunter, UK).

\section{Inocula}

Sewage sludge samples were obtained from St. Marys Sewage Treatment Plant Sydney, Australia and stored anaerobically in the dark at $4{ }^{\circ} \mathrm{C}$. Soil samples from Botany Bay, Sydney, Australia were core drilled from 3.6 meters beneath the surface and stored in the dark at room temperature in anaerobic media. Soil samples from $5 \mathrm{~cm}$ beneath the surface of Colo River area in Wollemi National Park, Blue Mountains Australia, were stored in the dark at room temperature.

\section{Microbial strains}

Acetobacterium species A. woodii DSM 1030, A. malicum DSM 4132, and A. wieringae DSM 1911 were obtained from Deutsche Sammlung von Mikroorganismen und Zellkulturen (DSMZ, Germany).

\section{Culture conditions}

Cells were grown in minimal media containing $\mathrm{NH}_{4} \mathrm{Cl}$ $\left(1.2 \mathrm{~g} \mathrm{l}^{-1}\right), \mathrm{MgCl}_{2} \cdot 2 \mathrm{H}_{2} \mathrm{O}\left(0.4 \mathrm{~g} \mathrm{l}^{-1}\right)$, and $\mathrm{CaCl}_{2} \cdot 2 \mathrm{H}_{2} \mathrm{O}$ $\left(0.1 \mathrm{~g} \mathrm{l}^{-1}\right)$. The media was dispensed into culture flasks, flushed with nitrogen for $20 \mathrm{~min}$, crimp-sealed with Teflon faced rubber septa and autoclaved. After autoclaving trace element mixture ( $\mathrm{HCl}(25 \%), 10 \mathrm{ml} ; \mathrm{FeCl}_{2}$. $4 \mathrm{H}_{2} \mathrm{O}, 2150 \mathrm{mg} ; \mathrm{MnCl}_{2} \cdot 4 \mathrm{H}_{2} \mathrm{O}, 30 \mathrm{mg} ; \mathrm{CoCl}_{2} \cdot 6 \mathrm{H}_{2} \mathrm{O}$, $50 \mathrm{mg} ; \mathrm{CuCl}_{2} \cdot 2 \mathrm{H}_{2} \mathrm{O}, 34 \mathrm{mg} ; \mathrm{NiCl}_{2} \cdot 6 \mathrm{H}_{2} \mathrm{O}, 20 \mathrm{mg}$; $\mathrm{Na}_{2} \mathrm{MoO}_{2} \cdot 2 \mathrm{H}_{2} \mathrm{O}, 30 \mathrm{mg} ; \mathrm{ZnSO}_{4} \cdot 7 \mathrm{H}_{2} \mathrm{O}, 24 \mathrm{mg} ; \mathrm{H}_{3} \mathrm{BO}_{3}$, $20 \mathrm{mg}$; distilled water, $1 \mathrm{l}$ ), $1 \mathrm{ml}$ vitamin solution (niacin, $100 \mathrm{mg}$; thiamine hydrochloride, $100 \mathrm{mg}$; biotin, $40 \mathrm{mg}$; pyridoxol hydrochlorid, $100 \mathrm{mg}$; folic acid, $20 \mathrm{mg}$; riboflavin, $50 \mathrm{mg}$; lipoic acid, $50 \mathrm{mg}$; pantothenic acid, $50 \mathrm{mg}$; Vitamin B12, $7.8 \mathrm{mg}$; 4-aminobenzoic acid, $50 \mathrm{mg}$; distilled water, $1 \mathrm{1}$ ), and $12.5 \mathrm{ml}$ of $1 \mathrm{M}$ phosphate buffer (prepared from $1 \mathrm{M} \mathrm{K}_{2} \mathrm{HPO}_{4}$ solution by adjusting $\mathrm{pH}$ value to 7.0 with $1 \mathrm{M} \mathrm{NaH}_{2} \mathrm{PO}_{4}$ ) were added aseptically per liter of media. Vitamins were filter sterilized and all other solutions were autoclaved. Cultures were incubated at $25^{\circ} \mathrm{C}$ in the dark.

\section{Initial enrichment cultures for isoprene reduction}

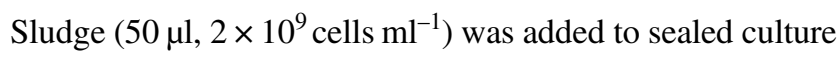
flasks $(120 \mathrm{ml})$ containing $80 \mathrm{ml}$ anaerobic minimal media. D/L-Lactate was supplied at $\sim 10 \mathrm{mM}$ from a sterile stock solution and isoprene was added as an electron acceptor from a $99.9 \%$ stock solution by using a $100 \mu \mathrm{l}$ glass syringe to a final concentration of $1.3 \mathrm{mM}$ in liquid media. Dilution to extinction series $\left(10^{-1}-10^{-6}\right)$ were performed using the same culture condition except in $60 \mathrm{ml}$ flask containing $40 \mathrm{ml}$ anaerobic minimal media.

\section{Growth in $\mathrm{H}_{2}$ and $\mathrm{HCO}_{3}{ }^{-}$containing media}

Anaerobic culture flask $(120 \mathrm{ml})$ containing $80 \mathrm{ml}$ minimal media were supplied with 0.5 bar sterile filtered $\mathrm{H}_{2}$ and $30 \mathrm{mM} \mathrm{NaHCO}$. Isoprene was added from a $99.9 \%$ stock solution by using a $100 \mu \mathrm{l}$ glass syringe to a final concentration of $1.3 \mathrm{mM}$ in liquid media. In the case of ethylene it was added from a $99.5 \%$ gas stock via a $5 \mathrm{ml}$ and $0.5 \mathrm{ml}$ gas tight syringe to 0.38 or $0.02 \mathrm{mM}$ in liquid media. Cultures were inoculated with isoprene reducing enrichment culture $(1 \mathrm{ml})$. In case of fructose it was added from a $1 \mathrm{M}$ anaerobic stock solution to a final concentration of $20 \mathrm{mM}$.

\section{Standards}

Standards were prepared in $120 \mathrm{ml}$ flasks with $80 \mathrm{ml}$ anaerobic minimal medium. Isoprene was added from stock solution with a glass syringe to prepare standards reaching 
from 0.4 to $5 \mathrm{mM}$ nominal concentrations. 3-methyl-1butene, 2-methyl-2-butene, and 2-methyl-1-butene were added from each stock solution with a glass syringe and combined in one flask as a standard reaching from 0.4 to 5 $\mathrm{mM}$ nominal concentrations. $\mathrm{H}_{2}$ was added from a $\mathrm{H}_{2}$ generator with standards reaching from 0.2 to $20 \mathrm{mM}$ nominal concentrations. Ethane, ethylene, and methane standards were prepared from a gas mixture $33.33 \%$ gas each) to prepare standards reaching from 0.1 to $12 \mathrm{mM}$ nominal concentrations. All gases were added with different sizes of gas tight syringes. Dimensionless Henry constants for isoprene, ethylene, ethane, methylbutenes, $\mathrm{H}_{2}$, and methane were calculated from Sander [36].

\section{Isoprene, $\mathrm{H}_{2}, \mathrm{HCO}_{3}{ }^{-}$, and hydrocarbon analysis}

Isoprene, methylbutenes, methane, $\mathrm{H}_{2}, \mathrm{CO}_{2}$ and hydrocarbon gases were monitored by gas chromatography (GC) using a Shimadzu GC-2010. Isoprene, methylbutenes and methane were analyzed by using a GasPro PLOT column (60 m x $0.32 \mathrm{~mm}$, Agilent Technologies) with Helium as a carrier gas $\left(3 \mathrm{ml} \mathrm{min}^{-1}\right)$ and flame ionization detection (FID). The oven temperature was $150{ }^{\circ} \mathrm{C}$ for $30 \mathrm{~s}$ and was increased by $20^{\circ} \mathrm{C} \mathrm{min}^{-1}$ to a final temperature of $250^{\circ} \mathrm{C}$. Gas samples $(100 \mu \mathrm{l})$ were withdrawn from the flask via a pressure-lockable gas tight syringe and directly injected into the GC.

$\mathrm{H}_{2}$ was analyzed using a HP-PLOT Molesieve column $(30 \mathrm{~m} \times 0.32 \mathrm{~mm} \times 0.25 \mathrm{~mm}$, Agilent Technologies, Australia) and pulsed discharged ionization detector (PDD). The carrier gas was Helium $\left(3 \mathrm{ml} \mathrm{min}^{-1}\right)$ and the oven temperature was applied at $50^{\circ} \mathrm{C}$ for $1.2 \mathrm{~min}$. Gas samples $(20 \mu \mathrm{l})$ were withdrawn from the flask via a gas lock syringe and directly injected into the Shimadzu GC-2010.

$\mathrm{HCO}_{3}{ }^{-}$concentrations were measured by acidification of media $(100 \mu \mathrm{l})$ in a sealed flask resulting in the release of $\mathrm{HCO}_{3}{ }^{-}$in form of $\mathrm{CO}_{2} . \mathrm{CO}_{2}$ was measured by GC-PDD using a HP-PLOT Q column $(30 \mathrm{~m} \times 0.32 \mathrm{~mm}$, Agilent Technologies, Australia). The carrier gas was Helium $\left(3 \mathrm{ml} \mathrm{min}{ }^{-1}\right)$ and the oven temperature was applied from $50{ }^{\circ} \mathrm{C}$ for $1 \mathrm{~min}$ to $54.5^{\circ} \mathrm{C}$ with a rate of $3.5^{\circ} \mathrm{C}$. Gas samples $(40 \mu \mathrm{l})$ were withdrawn from the flask via a gas lock syringe and directly injected into a Shimadzu GC-2010.

Formate, acetate, butyrate, and propionate were analyzed as their ethyl ester derivative by GC-FID using a DB-FFAP column ( $30 \mathrm{~m} \times 0.32 \mathrm{~mm} \times 0.25 \mathrm{~mm}$, Agilent Technologies) at $40{ }^{\circ} \mathrm{C}$ for $6 \mathrm{~min}$ with helium as the carrier gas $\left(3 \mathrm{ml} \mathrm{min}{ }^{-1}\right)$. Samples $(500 \mu \mathrm{l}$ media) were supplied with $100 \%$ ethanol $(200 \mu \mathrm{l})$ and undiluted sulfuric acid $(200 \mu \mathrm{l})$ for esterification, sealed immediately and incubated at $60{ }^{\circ} \mathrm{C}$ for $45 \mathrm{~min}$. Before injection into the $\mathrm{GC}$ samples were incubated at $80^{\circ} \mathrm{C}$ for $5 \mathrm{~min}$ at $500 \mathrm{rpm}, 250 \mu \mathrm{l}$ of headspace sample was withdrawn from the flask via an automatic sampler (Shimadzu AOC-5000 plus) and directly injected into a Shimadzu Plus $\mathrm{GC}-2010$ at $500 \mu \mathrm{s} \mathrm{s}^{-1}$.

Ethene and ethane amounts were measured by GC-FID using a GS-Q column $(30 \mathrm{~m} \times 0.32 \mathrm{~mm} \times 0.25 \mathrm{~mm})$ at $100{ }^{\circ} \mathrm{C}$ for $2 \mathrm{~min}$ with helium as the carrier gas $\left(3 \mathrm{ml} \mathrm{min}^{-1}\right)$. Gas samples $(100 \mu \mathrm{l})$ were withdrawn from the flask via a gas lock syringe and directly injected into a Shimadzu GC-2010.

\section{D/L-Lactate analysis}

Lactate concentrations were monitored by using the D/L-lactic acid kit from Megazyme following manufacturer's instructions.

\section{DNA extraction and Illumina sequencing}

DNA was extracted from $300 \mu \mathrm{l}$ culture using standard phenol-chloroform extraction method. Lysis buffer [37] was added to the sample and the tube was mechanically agitated in FastPrep Lysis Matrix A tubes (MP Biomedicals). DNA was extracted with sequential phenol (phenolchloroform-isoamyl alcohol (25:24:1), 7.5 M ammonium acetate, chloroform and isopropanol treatments, precipitated with ethanol using a general protocol, resuspended in $20 \mu \mathrm{l}$ $\mathrm{H}_{2} \mathrm{O}$ and stored at $-20{ }^{\circ} \mathrm{C}$ until further analysis. Regions of 16S rDNA gene were amplified by PCR from extracted DNA with the Q5 high-fidelity DNA polymerase (New England BioLabs) using the universal primers $926 \mathrm{~F}$ (5'-TCGTCGGCAGCGTCAGATGTGTATAAGAGACA G -[AAA CTYAAAKGAATTGRCGG]-3') and 1392R (5'GTCTCGTGGGCTCGGAGATGTGTATAAGAGACA G -[ACG GGC GGT GTG TRC-3') targeting bacteria and archaea [38]. The samples were sequenced on an Illumina MiSeq Sequencer (Illumina, USA) using V3 chemistry at the Next Generation Sequencing Facility at Western Sydney University's Hawkesbury Institute for the Environment (Sydney, Australia). In all, 16S rRNA gene amplicon sequences were analyzed with QIIME2 (https://qiime2.org) [39] utilizing the dada2 pipeline [40]. Sequencing quality was first visualized with FastQC (www.bioinformatics.ba braham.ac.uk) resulting in forwards and reverse reads being trimmed at 290 base pairs and 240 base pairs, respectively. Forward and reverse sequences that passed the default quality control were merged and non-overlapping sequences were discarded. Chimeras were analyzed and removed via the consensus method within the dada2 pipeline. Remaining sequences had taxonomy assigned with the RDP classifier [41] using the Greengenes 13_8 database [42]. Taxa present at $<2 \%$ abundance were removed for clarity. 


\section{Cloning}

In all, 16S rDNA gene fragment cloning was performed on DNA samples from the isoprene reducing culture after 29 days [Fig. 7]. Part of the Acetobacterium 16S rDNA fragment was PCR-amplified with the Aceto572F and Aceto784R [43] and a constant annealing temperature of $59^{\circ} \mathrm{C}$ for 34 cycles. All products were cloned into the $\mathrm{pCR}^{\mathrm{TM}} 2.1-\mathrm{TOPO}^{\circledR}$ vector with TOPO TA Cloning Kit (Invitrogen, Carlsbad, CA) according to manufacturer's instructions. Plasmid DNA was extracted from overnight Escherichia coli (DH5 $\left.\alpha^{\mathrm{TM}}-\mathrm{T} 1^{\circledR}\right)$ cultures using the PureYield ${ }^{\mathrm{TM}}$ Plasmid Miniprep System (Promega, Fitchburg, WI).

\section{Quantitative real-time PCR}

Quantitative real-time PCR targeting Acetobacterium was performed on a Biorad real-time PCR system by using QuantiTect SYBR green PCR mastermix (Qiagen, Germany) and Acetobacterium primers Aceto572F and Aceto784R. The thermocycling program was as follows: initial denaturation for $3 \mathrm{~min}$ at $98^{\circ} \mathrm{C}$; 39 cycles of $\left[95^{\circ} \mathrm{C}\right.$ for $20 \mathrm{~s}, 59^{\circ} \mathrm{C}$ annealing for $50 \mathrm{~s}$ ] and a final melting curve analysis from 60 to $99^{\circ} \mathrm{C}$. The standard curve was generated with serial dilutions of a known quantity of $16 \mathrm{~S}$ rDNA Acetobacterium gene-contained in plasmids generated as described above. Five copies of $16 \mathrm{~S}$ rRNA genes per Acetobacterium genome were calculated based on the sequenced genome of $A$. woodii DSM 1030 to convert gene copies to cell numbers [44].

\section{Results}

\section{Isoprene transformation in anaerobic microcosms}

Isoprene did not serve as an electron donor for the reduction of $\mathrm{SO}_{4}{ }^{2-}, \mathrm{NO}_{3}{ }^{2-}$, and $\mathrm{Fe}^{3+}$ after 12 months of observation in any of the tested inocula (data not shown). However, the evolution of isoprene reduction products 2-methyl-1-butene ( $>97 \%)$, 3-methyl-1-butene ( $\leq 2 \%)$, and 2-methyl-2-butene $(\leq 1 \%)$ was observed in activated sludge microcosms, suggesting the compound is reduced by the inocula [Mass spectra: Supplementary Fig. S1]). To investigate the reduction of isoprene more closely quadruplicate anaerobic microcosms were prepared with lactate $(900 \mu$ moles $)$ as the carbon and energy source, isoprene $(160 \mu$ moles $)$ as the electron acceptor, and activated sludge as inoculum $(1.7 \times$ $10^{7}$ cells ml ${ }^{-1}$ final concentration).

In the first round of enrichment cultures, isoprene depleted at a rate of $\sim 0.3 \mu$ moles per day after a 50 day lag period, with concomitant production of $15 \mu$ moles methylbutenes after 200 days [Fig. 1a, b]. The
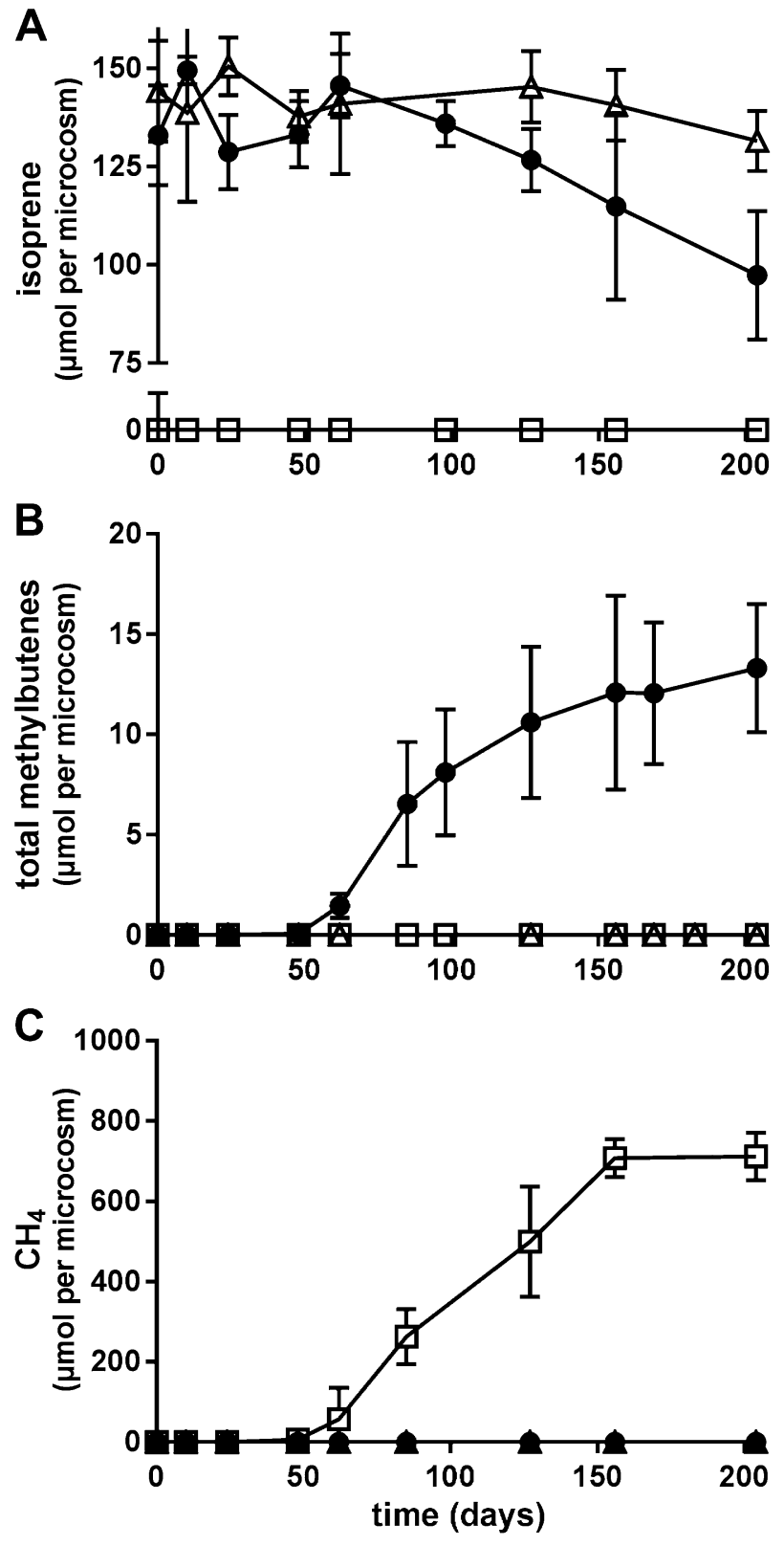

lactate + isoprene $\sharp$ lactate $\Delta$ isoprene

Fig. 1 Depletion of isoprene (a) and subsequent production of methylbutenes (b) was only observed in microcosms containing sludge, lactate, and isoprene. In control samples supplemented with only lactate or isoprene, no isoprene depletion or methylbutene formation was detected. Methane (c) production only occurred in cultures supplied with lactate. Error bars represent one standard deviation $(n=4)$

predominant isoprene reduction product was 2-methyl-1butene $(98 \%, 12.3 \mu \mathrm{moles})$, with lesser amounts of 3-methyl-1-butene $(2 \%)$. Lactate $(900 \mu$ moles $)$ was completely consumed after 50 days in the presence or absence of isoprene [Fig. 2a] and was fermented to acetate, propionate $\left(400 \mu\right.$ moles each), $\mathrm{H}_{2}$ with associated biomass generation [Fig. 2b-e]. Isoprene reduction occurred 

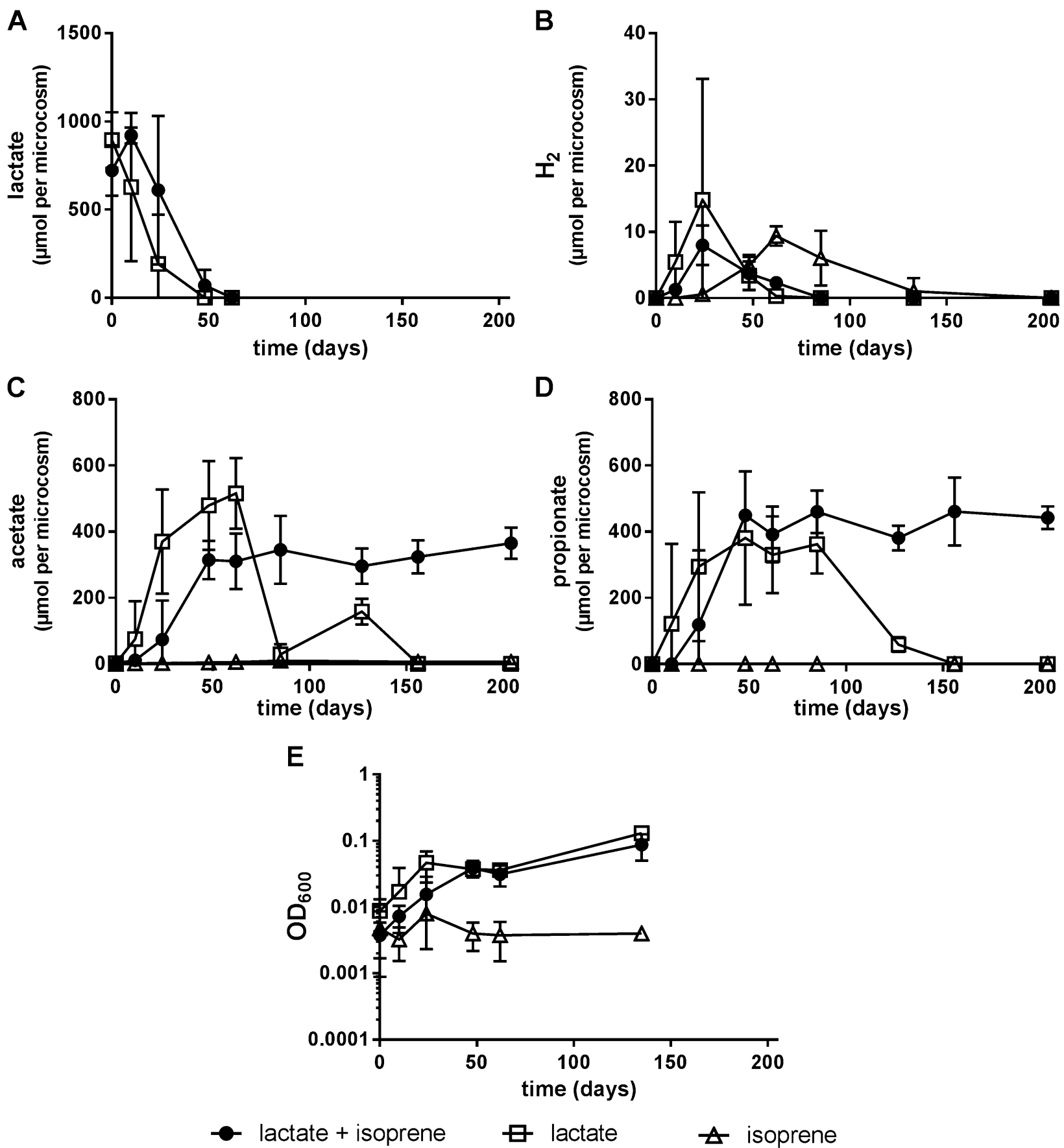

Fig. 2 Change in quantity of lactate (a), $\mathrm{H}_{2}(\mathbf{b})$, acetate (c), propionate (d), and biomass formation (e) in anaerobic cultures containing sludge and amended with lactate, isoprene, or both. Acetate and propionate were depleted in cultures with lactate only but concentrations remained stable after day 200 in cultures with isoprene and lactate. Error bars represent one standard deviation $(n=4)$ subsequent to lactate consumption (after 50 days). Cultures without lactate amendment generated low quantities of fatty acids $(<6 \mu$ moles $)$ and $\mathrm{H}_{2} \quad(\sim 3-10 \mu$ moles $)$ presumably derived from biomass supplied in the inoculum, but did not convert isoprene to methylbutenes. Methane production was not detected in the presence of isoprene and lactate, however in the presence of lactate alone methane production commenced after 48 days and increased to $700 \mu$ moles within 100 days with associated depletion of acetate and propionate [Figs. 1c and 2c, d]. Autoclaved and uninoculated controls did not show any depletion of isoprene or formation of methylbutenes. 
Fig. 3 Composition of the bacterial and archaeal populations classified at Family level and if possible on Genus level of sludge during growth on lactate + isoprene (a) and lactate only control (b) at time points 0 , 156, and 204 days. Samples were inoculated with wastewater from St. Marys treatment plant. Other category is the sum of all classifications with $<2 \%$ abundance. Classifications in the legend are clustered according to their phylum (from top to bottom); Actinobacteria, WWE1, Bacteroidetes, Proteobacteria, Spirochaetes, Firmicutes,

Planctomycetes, Euryarchaeota.

Depleted amounts of isoprene in each replicate are shown at the top. Only three out of four replicates were analyzed by Illumina sequencing

\section{A}
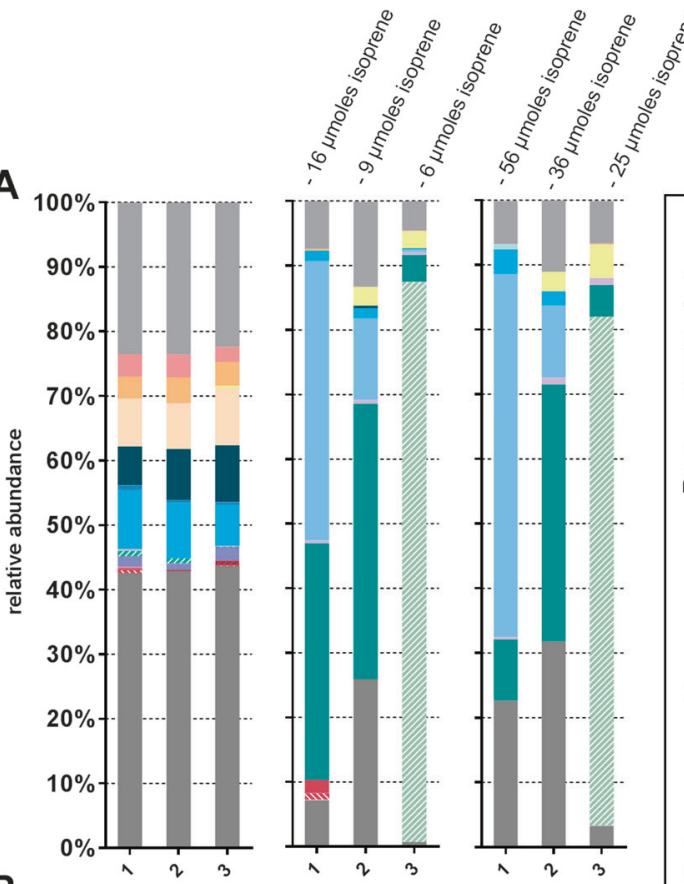

B

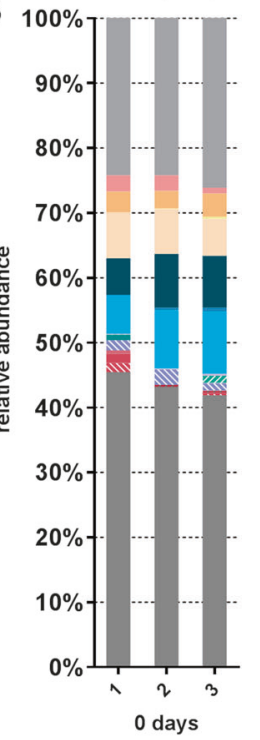

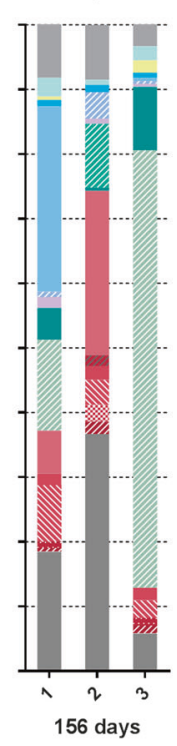

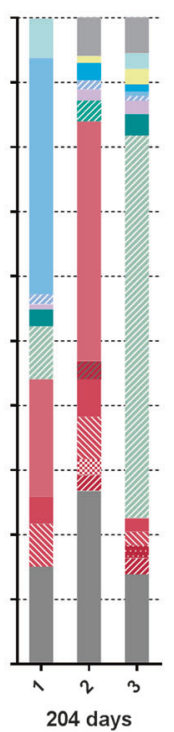

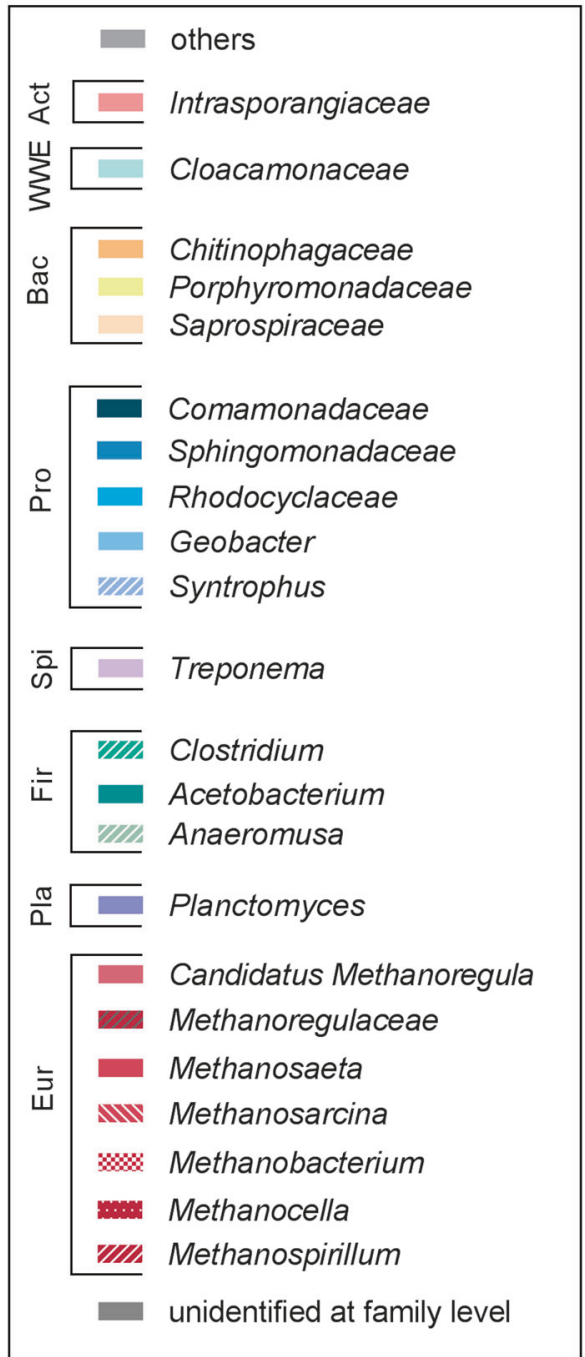

\section{Community analysis of lactate driven anaerobic isoprene transformations}

Bacterial and archaeal community analysis was performed using 16S rRNA gene amplicons derived from DNA extracted from the lactate and isoprene fed cultures sampled before and after isoprene consumption [Fig. 3]. In the isoprene fed cultures, Acetobacterium, Geobacter, and in one replicate Anaeromusa where found to be the dominant bacterial genera [Fig. 3a]. Cultures supplied with lactate but without isoprene were dominated by a consortium of methanogenic archaea and bacteria Geobacter, Clostridium, Acetobacterium, and Anaeromusa [Fig. 3b].

\section{Characterization of $\mathrm{H}_{2}$ driven isoprene transformations}

The lag in isoprene reduction relative to lactate depletion suggested that lactate fermentation products were serving as carbon and energy sources. Given that acetate and propionate concentrations remained stable after day 200 in cultures amended with isoprene [Fig. 2c, d] it was hypothesized that $\mathrm{H}_{2}$ and $\mathrm{HCO}_{3}{ }^{-}$were serving as electron donor and carbon source, respectively.

To test this hypothesis a dilution to extinction experiment was set-up with $\mathrm{H}_{2}$ as the electron donor, $\mathrm{HCO}_{3}{ }^{-}$as the carbon source, and isoprene as the electron acceptor using a 

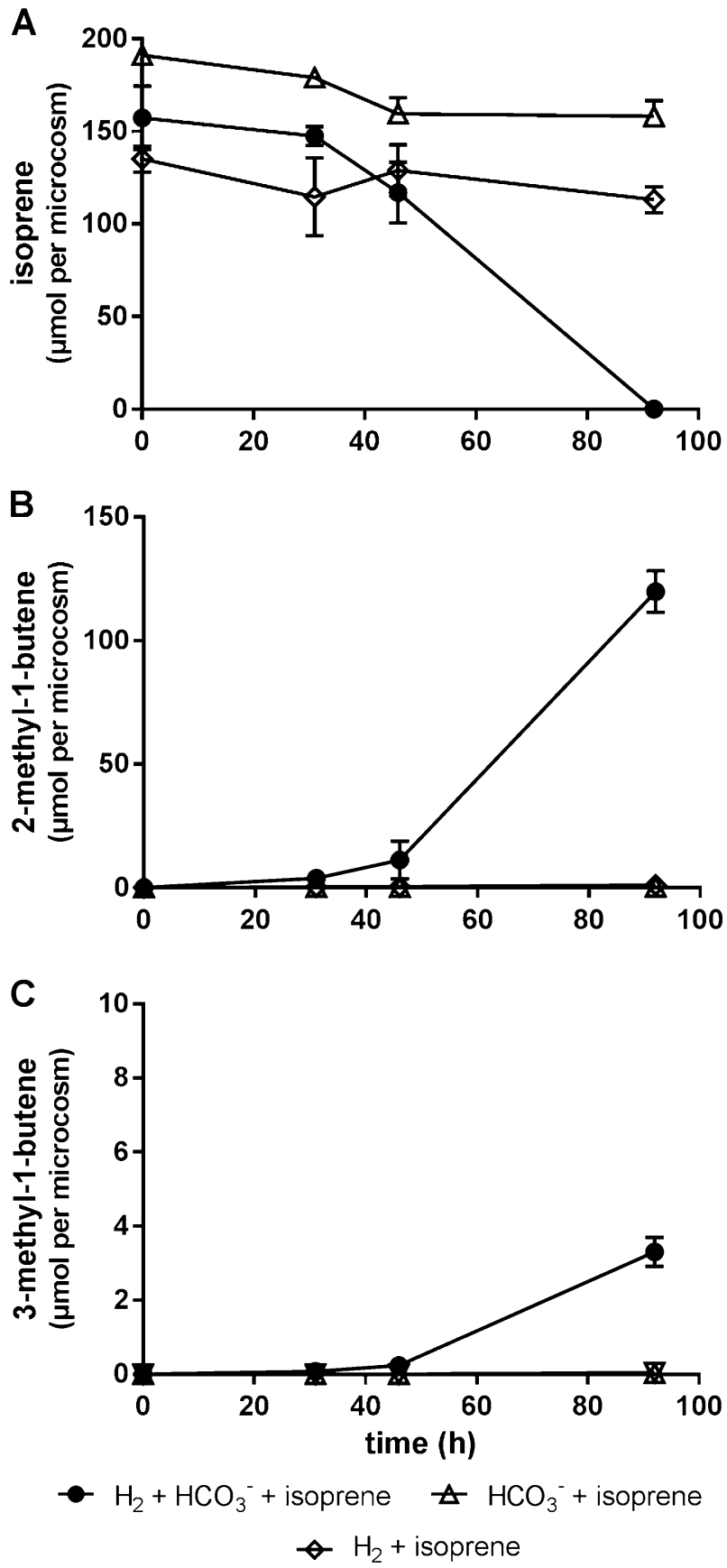

Fig. 4 Depletion of isoprene (a) in $80 \mathrm{ml}$ anaerobic cultures containing an enriched isoprene reducing culture supplied with $\mathrm{H}_{2}+\mathrm{HCO}_{3}{ }^{-}+$ isoprene and reciprocal production of 2-methyl-1-butene (b) and 3methyl-1-butene (c). In control samples supplemented with only $\mathrm{H}_{2}+$ isoprene or only $\mathrm{HCO}_{3}{ }^{-}+$isoprene no methylbutene formation or isoprene depletion was detected. Error bars represent one standard deviation $(n=4)$

pooled enrichment culture derived from lactate and isoprene amended cultures as an inoculum. Isoprene reduction was observed in the $10^{-6}$ dilution with isoprene quantitatively transformed to 2-methyl-1-butene $(98 \%)$ at a rate of $1.6 \mu$ moles $^{-1}$.

Having established the defined conditions for the cultivation of isoprene reducing bacteria (i.e., $\mathrm{H}_{2} / \mathrm{HCO}_{3}{ }^{-}$/isoprene), quadruplicate cultures were prepared to characterize $\mathrm{H}_{2} /$ $\mathrm{HCO}_{3}{ }^{-}$/isoprene consumption rates and formation of volatile fatty acids (i.e., acetate, and formate). Isoprene (130 $\mu$ moles) was transformed to methylbutenes $(125 \mu$ moles $)$ within $92 \mathrm{~h}$ [Fig. 4a-c]. The predominant methylbutene was 2-methyl-1butene $(97 \%)$ with lesser amounts to 3-methyl-1-butene (2\%), and 2-methyl-2-butene $(\leq 1 \%)$ [Fig. 4b, c]. Depletion of $\mathrm{H}_{2}$ and $\mathrm{HCO}_{3}{ }^{-}$correlated with an increase in acetate. There was no significant difference in $\mathrm{H}_{2}$ and $\mathrm{HCO}_{3}{ }^{-}$depletion or acetate and formate production when comparing isoprene and isoprene free cultures [Fig. 5a-d]. When cultures were incubated with isoprene and $\mathrm{H}_{2}$ or isoprene and $\mathrm{HCO}_{3}$, neither acetate formation nor isoprene reduction was observed. To determine if methylbutene can be further reduced, $\mathrm{H}_{2}$ was resupplied. After 8 days no further reduction of methylbutene to methylbutane was observed [Supplementary Fig. S2].

\section{Community analysis of $\mathrm{H}_{2}$ driven anaerobic isoprene transformations}

Illumina sequencing of $16 \mathrm{~S}$ rRNA gene amplicons from $\mathrm{H}_{2}$ supplied, isoprene reducing enrichment cultures revealed enrichment of Acetobacterium to $92-100 \%$ relative abundance [Figs. 4a and 6]. Comamonadaceae were also present $(2-7 \%)$. There was no notable difference between bacterial community compositions in the presence vs. absence of isoprene [Fig. 6].

To further probe an isoprene dependent difference in community composition a new set of cultures was monitored over a longer period by resupply of isoprene, $\mathrm{H}_{2}$, and $\mathrm{HCO}_{3}{ }^{-}$when depleted [Fig. 7]. Isoprene was depleted within 3-5 days after each resupply at a similar rate as observed before $\left(1.6 \mu\right.$ moles $\left.\mathrm{h}^{-1}\right)$ [Fig. 7a]. Methylbutene accumulated up to $800 \mu$ moles, respectively [Fig. 7b]. Illumina sequencing of $16 \mathrm{~S}$ rRNA amplicons again showed no appreciable difference in microbial community composition when comparing cultures with or without isoprene. Both communities were once again dominated by Acetobacterium spp. [Supplementary Fig. S3]. Additionally, Acetobacterium cell numbers were similar after 29 days (i.e., $\sim 4.8 \times 10^{7} \pm 1.3 \times 10^{7}$ cells ml $^{-1}$ for cultures with isoprene and $5.6 \times 10^{7} \pm 2.8 \times 10^{7}$ cells ml $^{-1}$ for those without) [Fig. 7e]. Importantly, however, there was a significant difference in the amount of acetate produced in cultures with and without isoprene. After day 16, cultures with isoprene produced $\sim 250 \mu$ moles of acetate while those without produced $\sim 400 \mu$ moles [Fig. $7 \mathrm{c}$ ]. 
A

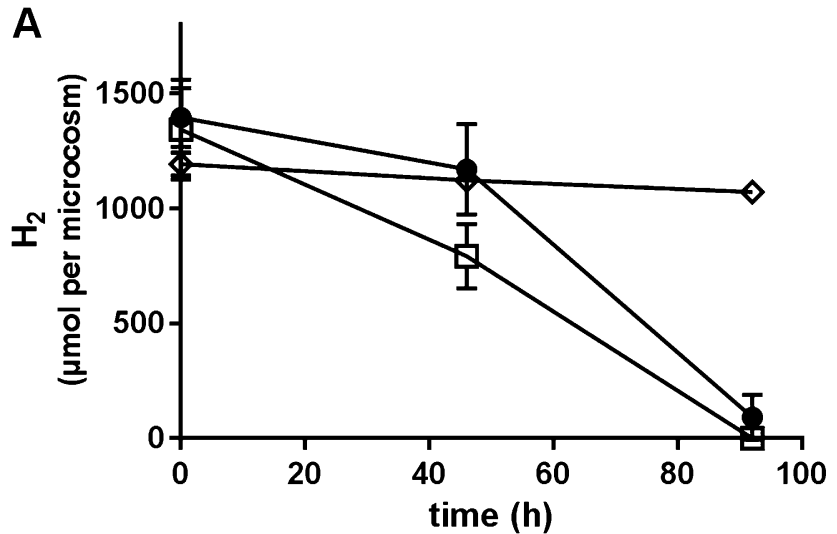

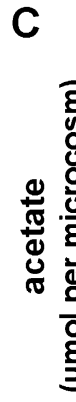

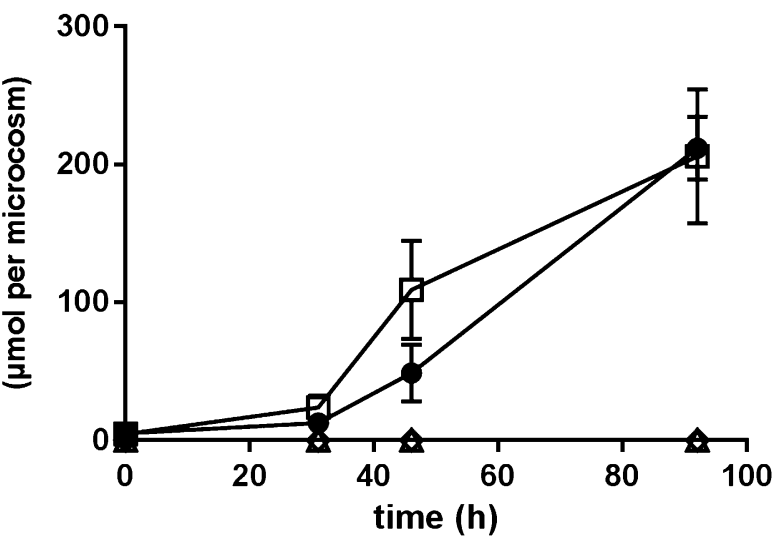

B

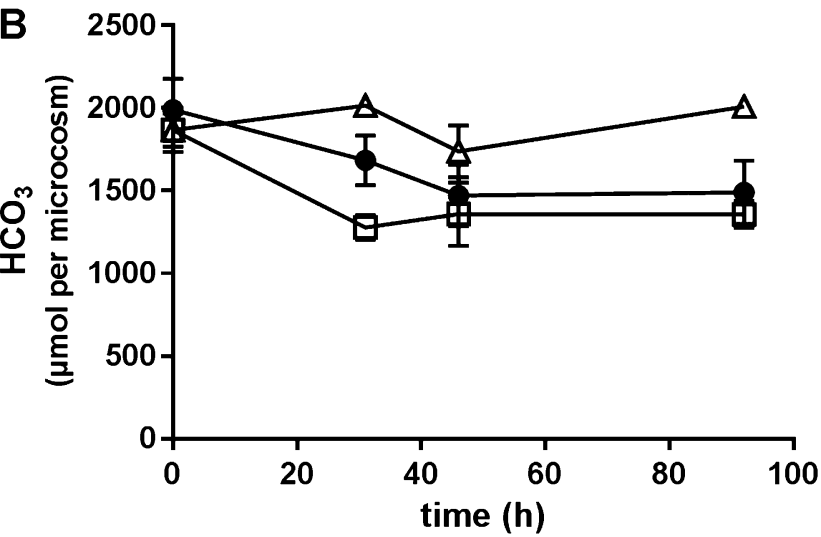

D

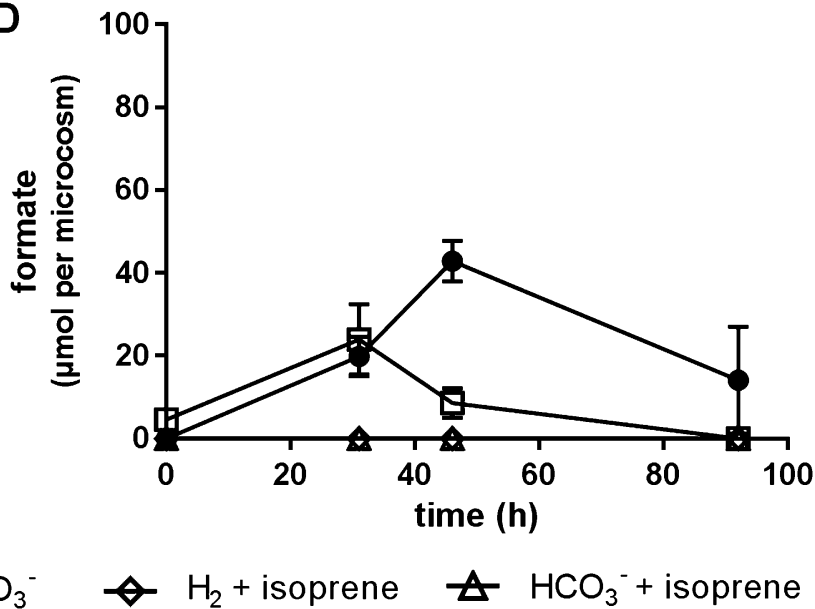

Fig. 5 Consumption of $\mathrm{H}_{2}$ (a) and $\mathrm{HCO}_{3}{ }^{-}$(b) and formation of acetate (c) and formate (d) anaerobic cultures containing an enriched isoprene reducing culture supplied with and without isoprene. In control samples supplemented with $\mathrm{H}_{2}$ + isoprene or $\mathrm{HCO}_{3}{ }^{-}+$isoprene no acetate or formate formation was detected. Error bars represent one standard deviation $(n=4)$

and cells reduced $\mathrm{CO}_{2}$ to around $600 \mu$ moles of acetate [Supplement Figs. S4 and S5].

\section{Discussion}

\section{Isoprene serves as an electron acceptor}

Even though isoprene is a highly abundant, energy rich metabolite, little is known about its anaerobic metabolism. In this study we tested the utility of isoprene as both an electron donor for inorganic oxide reduction and as an electron acceptor where lactate and molecular $\mathrm{H}_{2}$ were electron donors.

Anaerobic isoprene oxidation coupled to inorganic oxide reduction $\left(\mathrm{SO}_{4}{ }^{2-}, \mathrm{NO}_{3}{ }^{2-}\right.$, or $\left.\mathrm{Fe}^{3+}\right)$ could not be demonstrated in any of the tested inocula after 1 year of incubation. Under standard conditions, anaerobic isoprene oxidation is exergonic, considering the theoretical stoichiometries of isoprene mineralization and $\mathrm{SO}_{4}{ }^{2-}, \mathrm{Fe}^{3+}$, or $\mathrm{NO}_{3}{ }^{-}$reduction (isoprene energy of formation calculated as 
Fig. 6 Composition of the bacterial populations at Family level and if possible on Genus level of the isoprene reducing culture during growth on $\mathrm{H}_{2}+$ $\mathrm{HCO}_{3}{ }^{-}+$isoprene and on $\mathrm{H}_{2}+$ $\mathrm{HCO}_{3}{ }^{-}$controls at different time points 0,46 , and $96 \mathrm{~h}$. Other category is the sum of all classifications with $<2 \%$ abundance. Error bars represent one standard deviation $(n=3)$. Classifications in the legend are clustered according to their phylum (from top to bottom); Firmicutes, Proteobacteria, Actinobacteria, Euryarchaeota

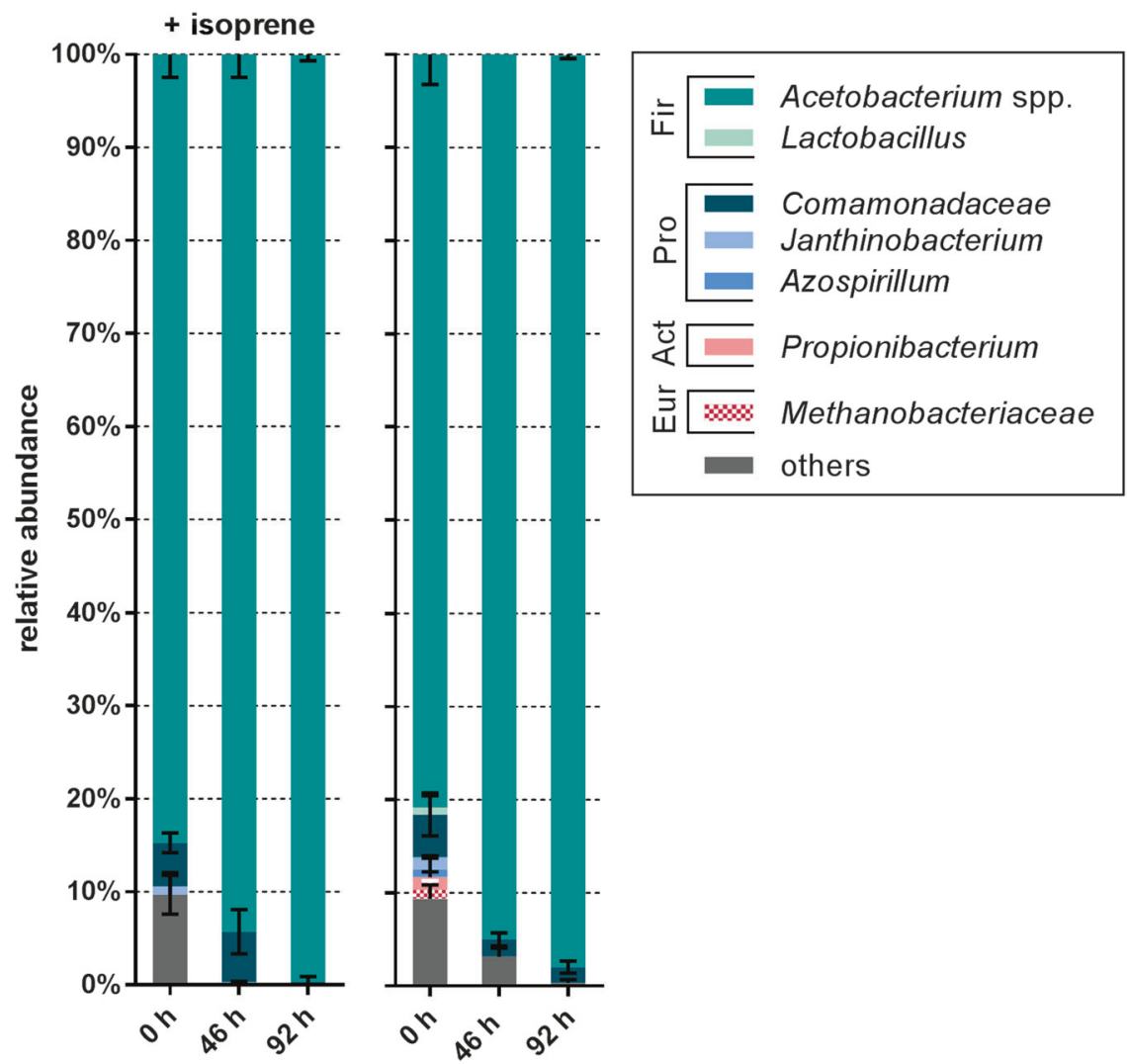

$197 \mathrm{~kJ} \mathrm{~mol}^{-1}[45,46]$.

$$
\begin{aligned}
& 2 \mathrm{C}_{5} \mathrm{H}_{8}+2 \mathrm{H}_{2} \mathrm{O}+7 \mathrm{SO}_{4}{ }^{2-} \rightarrow 7 \mathrm{HS}^{-} \\
& +3 \mathrm{H}^{+}+10 \mathrm{HCO}_{3}^{-} \\
& \Delta G^{\circ}=-605 \mathrm{~kJ} / \mathrm{mol}^{-1} \\
& \mathrm{C}_{5} \mathrm{H}_{8}+\mathrm{H}_{2} \mathrm{O}+14 \mathrm{NO}_{3}{ }^{-} \rightarrow 5 \mathrm{HCO}_{3}{ }^{-} \\
& +5 \mathrm{H}^{+}+14 \mathrm{NO}_{2}{ }^{-} \\
& \Delta G^{\circ}=-2044 \mathrm{~kJ} / \mathrm{mol}^{-1}
\end{aligned}
$$

$$
\begin{gathered}
28 \mathrm{Fe}^{3+}+\mathrm{C}_{5} \mathrm{H}_{8}+15 \mathrm{H}_{2} O \rightarrow 5 \mathrm{HCO}_{3}{ }^{-} \quad \Delta G^{\circ}=-2914 \mathrm{~kJ} / \mathrm{mol}^{-1} \\
+28 \mathrm{Fe}^{2+}+33 \mathrm{H}^{+}
\end{gathered}
$$

Evidently the enzyme systems required for the above transformations are either non-existent, extremely rare or inhibited or not induced under the conditions applied.

However, reductive isoprene transformation to 2-methyl1-butene, 3-methyl-1-butene, and 2-methyl-2-butene was observed under methanogenic conditions after 2 months of incubation. Subsequent enrichment resulted in increased rates of isoprene reduction (from $\sim 0.3 \mu$ moles per day to $40 \mu$ moles per day). Isoprene reduction to methylbutene is also thermodynamically favorable considering theoretical stoichiometries with $\mathrm{H}_{2}$ as electron donor [Fig. 8] [45, 47].

$$
\mathrm{H}_{2}+\mathrm{C}_{5} \mathrm{H}_{8} \rightarrow \mathrm{C}_{5} \mathrm{H}_{10} \quad \Delta G^{\circ}=-137 \mathrm{~kJ} / \mathrm{mol}^{-1}
$$

\section{Acetobacterium spp. reduce isoprene}

Illumina sequencing targeting archaeal and bacterial $16 \mathrm{~S}$ rRNA gene amplicons revealed that acetogenic Acetobacterium spp. dominated the isoprene reducing enrichment culture. Acetogens are anaerobic bacteria that use $\mathrm{CO}_{2}$ as a terminal electron acceptor for energy conservation and carbon fixation utilizing the reductive acetyl coenzyme A (acetyl-CoA) pathway or Wood-Ljungdahl pathway [48, 49]:

$$
\mathrm{CO}_{2}+4 \mathrm{H}_{2} \rightarrow \mathrm{CH}_{3} \mathrm{COOH}+2 \mathrm{H}_{2} \mathrm{O} \quad \Delta G^{\circ}=-105 \mathrm{~kJ} / \mathrm{mol}^{-1}
$$

They are a phylogenetically and metabolically diverse group using a variety of different electron donors and acceptors [50]. Reducing equivalents can be generated from oxidation of $\mathrm{H}_{2}, \mathrm{C}_{1}$-compounds like methanol and formate, sugars, organic acids, and alcohols [51]. Besides $\mathrm{CO}_{2}$, acetogens can also use alternative electron acceptors such as 
A
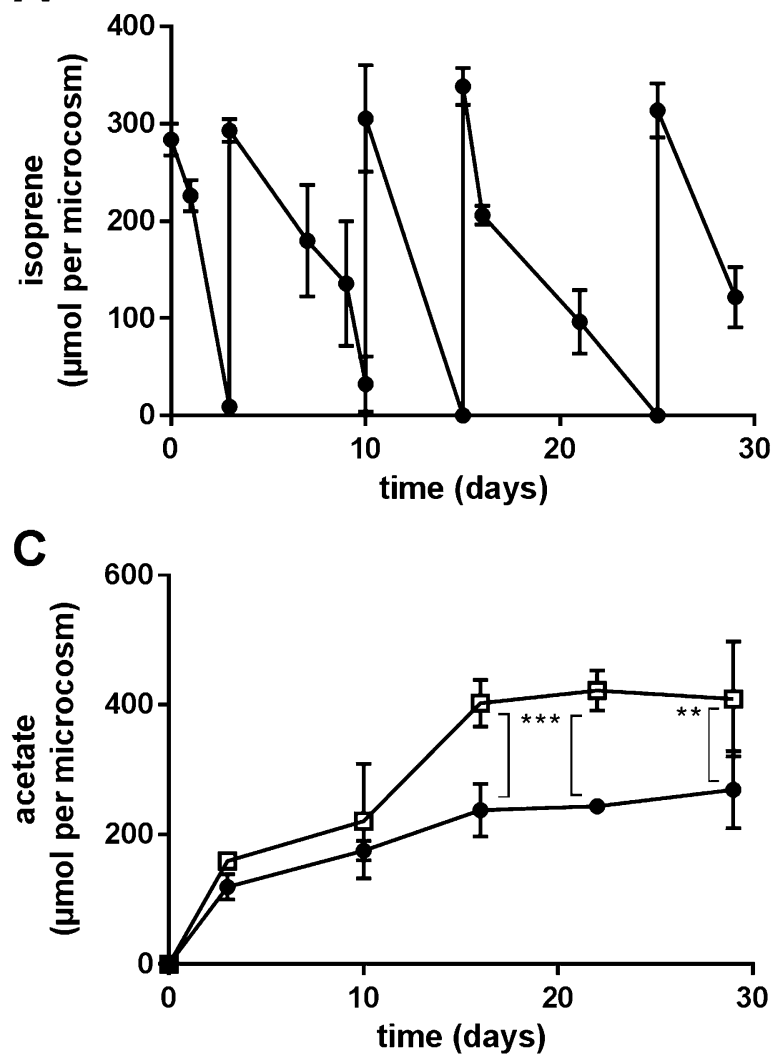

B

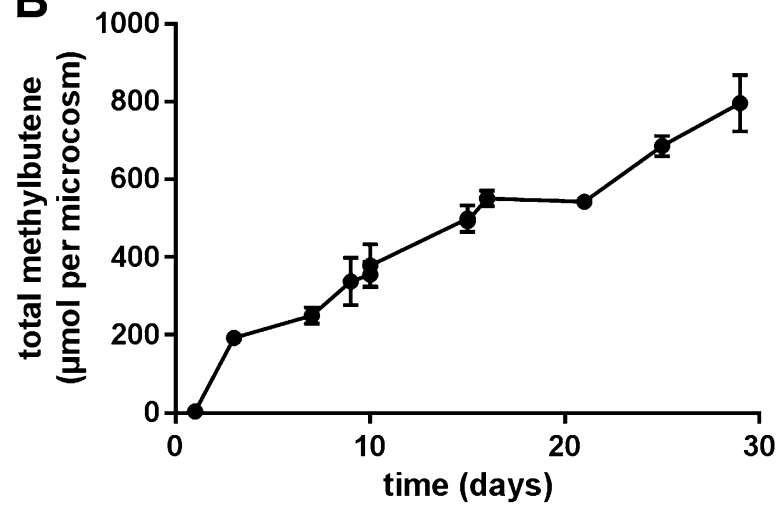

D

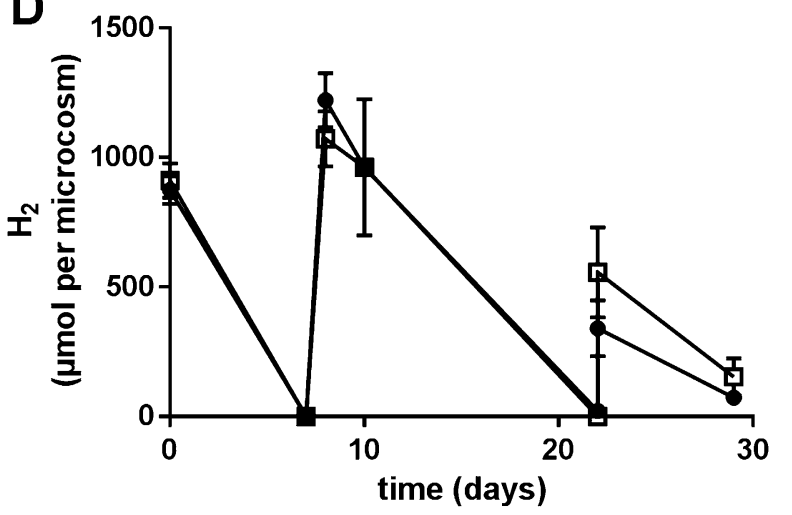

E

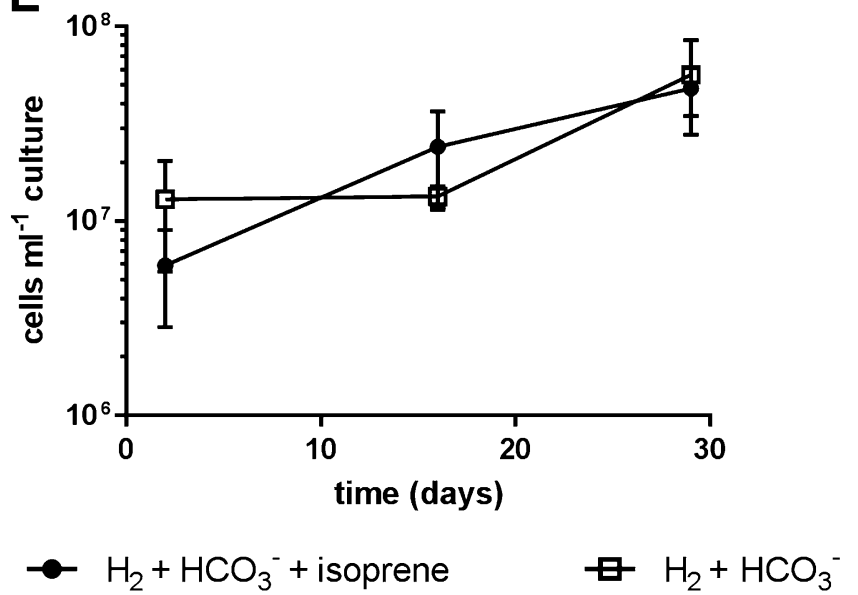

Fig. 7 Depletion of isoprene (a) and reciprocal production of total methylbutenes (b) in anaerobic cultures containing an enriched isoprene reducing culture amended with $\mathrm{H}_{2}$ and $\mathrm{HCO}_{3}{ }^{-}$with and without isoprene. Cultures amended with isoprene produced $40 \%$ less acetate (c) while still consuming the same amount of $\mathrm{H}_{2}(\mathbf{d})$. Acetobacterium cells $\mathrm{ml}^{-1}$ (e) calculated from $16 \mathrm{~S}$ rDNA gene copies $\mathrm{ml}^{-1}$ demonstrate equivalent growth in both conditions. ***p-value $<0.0001, * * p$ value $=0.005$ analyzed by a two-way ANOVA. Error bars represent one standard deviation $(n=4)$

As shown in this study, Acetobacterium spp. appear also to utilize isoprene as an alternative electron acceptor to $\mathrm{CO}_{2}$. Isoprene reduction to methylbutenes depended on the presence of $\mathrm{H}_{2}$ and $\mathrm{CO}_{2}$ [Fig. 4], common substrates for acetogens, which can otherwise only be metabolized by methanogens under anaerobic conditions. Methanogens acrylate derivatives [52], fumarate [53], nitrate [54], chlorethenes, chlorethanes [55], and brominated/aromatic compounds [44]. The best studied example for $\mathrm{CO}_{2}$-alternative electron acceptors in acetogens is the reduction of the carbon-carbon double bond in phenylacrylates (e.g., caffeate) by the model organism Acetobacterium woodii [52, 56, 57]. 
1.<smiles>C=CC(=C)CCCCCC(=C)CC</smiles>

2.

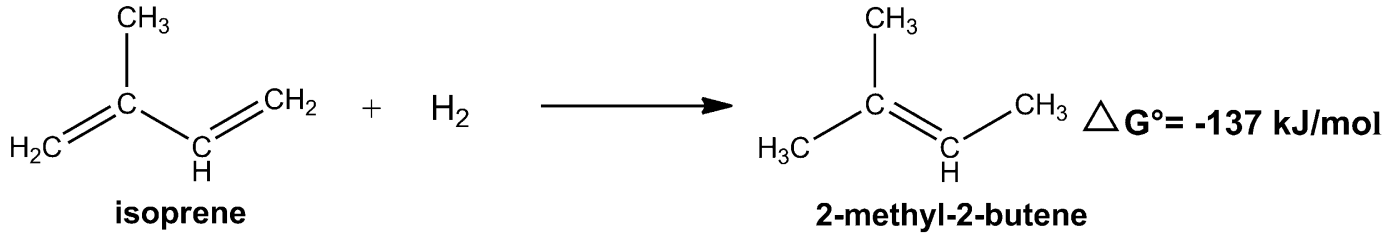

3.
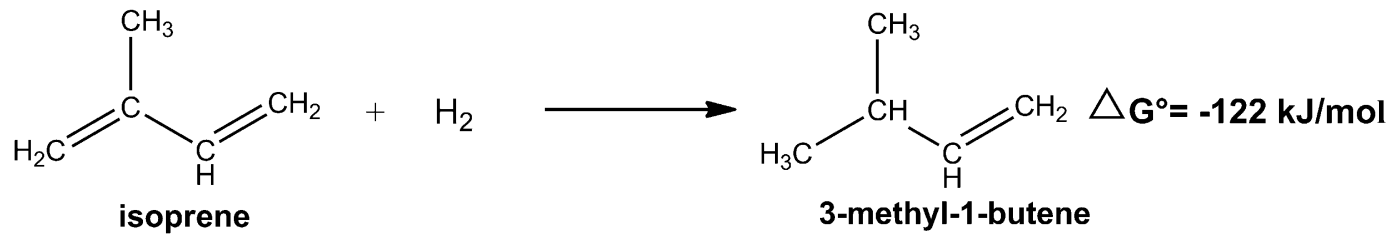

Fig. 8 Chemical equations and Gibbs free energy of formation of the reduction of isoprene to 3-methyl-1-butene, 2-methyl-1-butene, and 2methyl-2-butene with $\mathrm{H}_{2}$ as the electron donor. Gibbs free energy of

formation of isoprene was estimated by the group contribution method [44] to be $197 \mathrm{~kJ} \mathrm{~mol}^{-1}$

were not present in isoprene amended enrichment cultures and no methane formation was observed. In cultures resupplied with $\mathrm{H}_{2}, \mathrm{HCO}_{3}{ }^{-}$, and isoprene, $40 \%$ less acetate was formed compared to $\mathrm{H}_{2}$ and $\mathrm{HCO}_{3}{ }^{-}$supplied cultures [Fig. 7c] suggesting that the Acetobacterium spp. transferred electrons from $\mathrm{H}_{2}$ to isoprene at the expense of $\mathrm{CO}_{2}$ reduction. In cultures without isoprene, $400 \mu$ moles acetate were produced, which required oxidation of $1600 \mu$ moles $\mathrm{H}_{2}$ (Eq. 5) or $3200 \mu$ moles of electrons. However, cultures with isoprene produced only $240 \mu$ moles of acetate requiring $960 \mu$ moles $\mathrm{H}_{2}$. In addition $800 \mu$ moles $\mathrm{H}_{2}$ were required to reduce $800 \mu$ moles of isoprene. Altogether that totals $1760 \mu$ moles $\mathrm{H}_{2}$ or $3520 \mu$ moles of electrons transferred in cultures supplied with isoprene. Since similar amounts of electrons were transferred in cultures with (3520 $\mu$ moles) and without isoprene $(3200 \mu$ moles $)$ and similar cell densities in each condition were observed, it can be concluded that the shortage of acetate in isoprene amended microcosms results from the reduction of isoprene instead of $\mathrm{CO}_{2}$. Isoprene reduction might, therefore, also be coupled to energy conservation. Similar results were found by Hansen et al. [58] in the A. woodii NZva16 strain grown on $\mathrm{H}_{2}, \mathrm{CO}_{2}$, and caffeate, a key intermediate in lignin synthesis in plants. It was shown that $11 \mathrm{mM}$ caffeate was reduced to hydrocaffeate and $\sim 14-40 \%$ less acetate was formed compared to cultures without caffeate.

Considering the $\Delta G^{\circ}$ values of the isoprene/methylbutene couple (Eq. 4), isoprene reduction is energetically favored over $\mathrm{CO}_{2}$ reduction (Eq. 5). This could lead to preferential use of isoprene over $\mathrm{CO}_{2}$. However, in the case of caffeate (caffeate/hydrocaffeate), its reduction and

acetogenesis from $\mathrm{H}_{2}$ and $\mathrm{CO}_{2}$ were either catalyzed simultaneously or $\mathrm{CO}_{2}$ was preferred over caffeate $[56,58]$. Tschech and Pfennig [59] observed that caffeate was preferentially used over $\mathrm{CO}_{2}$ as an electron acceptor in the presence of methanol (methanol/caffeate 1:3). In the enrichment culture generated in this study, it remains to be tested whether isoprene reduction also occurs simultaneously catalyzed by a dominating Acetobacterium spp. by multiple or if one species only reduces isoprene and not $\mathrm{CO}_{2}$.

It was unexpected that pure Acetobacterium isolates (A. woodii DSM 1030, A. malicum DSM 4132, and A. wieringae DSM 1911) showed no isoprene reduction activity. However, Acetobacterium are a particularly tight phylogenetic group with 96-99\% 16S gene sequence similarity between species [60]. It is possible that an uncultured species of Acetobacterium is responsible for isoprene reduction, or the gene enabling the reduction was acquired via horizontal gene transfer. These possibilities will be investigated in future studies. Also, Comamonadaceae cannot be conclusively excluded from involvement in isoprene reduction as Illumina sequencing data did not reveal the genus of organisms present. There is a possibility that Hydrogenophaga lineages, some of which can oxidize $\mathrm{H}_{2}$ and fix $\mathrm{CO}_{2}$ [61], contribute to isoprene reduction.

Bioenergetics and growth efficiencies of acetogens can be evaluated by using the acetate-to-biomass ratios [62]. Even though less acetate was formed in isoprene amended cultures, similar cell densities were achieved. This suggests that isoprene reduction is coupled to ATP synthesis as shown for caffeate reduction by A. woodii [58]. The current 
model in A. woodii suggests that electrons flow from $\mathrm{H}_{2}$ to $\mathrm{NAD}^{+}$and ferredoxin, which are reduced by a electronbifurcating hydrogenase [58]. A $\mathrm{Na}^{+}$-translocating ferredoxin: $\mathrm{NAD}^{+}$-oxidoreductase then oxidizes ferredoxin (Rnf complex) and generates a $\mathrm{Na}^{+}$gradient over the cytoplasmic membrane for ATP synthesis [57, 63, 64]. It is possible that some of these enzymes might be involved in isoprene reduction. But in contrast to phenylacrylates, fumarate and chlorethenes, isoprene is an unsubstituted alkene making nucleophilic attack more difficult.

\section{Hydrogenation of isoprene}

In the present study, we have shown that isoprene is hydrogenated to three methylbutene isomers with proportions remaining constant throughout the experiments (2methyl-1-butene 98\%, 3-methyl-1-butene 1-2\%, and 2methyl-2-butene $<1 \%$ ) i.e., fully reduced alkanes were not produced [Supplementary Fig. S2]. Hydrogenation of a double bond is a thermodynamically favorable reaction because it forms a more stable (lower energy) product. The released heat is referred to as the heat of hydrogenation $\left(\Delta \mathrm{Hh}_{298}{ }^{\circ}\right)$, which reflects the stability of a molecule. Isoprene, due to its conjugated doubled bonds, has a $\Delta \mathrm{Hh}_{298^{\circ}}$ value of $-55 \mathrm{kcal} \mathrm{mol}^{-1}$ compared to its reduced forms $\left(\Delta \mathrm{Hh}_{298}{ }^{\circ}\right.$ 3-methyl-1-butene; $-29.9 \mathrm{kcal} \mathrm{mol}^{-1}$, 2-methyl1-butene; $\quad-28.24 \mathrm{kcal} \mathrm{mol}^{-1}$ and 2-methyl-2-butene; $-26.74 \mathrm{kcal} \mathrm{mol}^{-1}$ [65]. Therefore, reduction of a single double bond requires more activation energy and a different set of enzymes. This could explain why ethylene $\left(\mathrm{H}_{2} \mathrm{C}=\right.$ $\mathrm{CH}_{2}$ ) was not reduced to ethane by the active isoprene reducing culture. A few observations of microbial hydrogenation of ethylene to ethane have been made [66-69] but a pure bacterial culture or responsible enzymes have not been identified. It remains to be tested whether the enzymatic hydrogenation of isoprene to methylbutene occurs directly or via an intermediate hydration product (e.g., 3Methyl-3-buten-1-ol).

\section{The physiological role of isoprene reduction- metabolic strategies of acetogens}

Depletion of electron acceptors creates a niche for acetogens and methanogens due to their ability to obtain energy from $\mathrm{CO}_{2}$ reduction via $\mathrm{H}_{2}$ oxidation [70, 71]. In these environments acetogens compete with methanogens for $\mathrm{H}_{2}$.

$$
\mathrm{HCO}_{3}^{-}+4 \mathrm{H}_{2}+\mathrm{H}^{+} \rightarrow \mathrm{CH}_{4}+\mathrm{H}_{2} \mathrm{O} \quad \Delta G^{\circ}=-135 \mathrm{~kJ} / \mathrm{mol}
$$

Thermodynamically, hydrogenotrophic methanogenesis (Eq. 6) is favored over acetogenesis (Eq. 5), therefore acetogens are physiologically less competitive for $\mathrm{H}_{2}$ when it is a limiting resource. Yet, their ability to use different electron acceptors enhances the in situ competitiveness of acetogens [72, 73]. Given that $\Delta G^{\circ}$ values for hydrogenotrophic isoprene reduction (Eq. 4) and bicarbonate reduction to methane (Eq. 6) are equivalent, the use of isoprene as an alternative electron acceptor would enable acetogens to compete with methanogens at similar $\mathrm{H}_{2}$ threshold concentrations.

According to Lever et al. [70] there are two hypotheses for how the wide metabolic spectrum of acetogens enables them to coexist with sulfate reducers and methanogens. Firstly, metabolic versatility leads to niche differentiation with respect to substrate and secondly acetogens can pool energy from a broad range of metabolic reactions (e.g., simultaneous $\mathrm{CO}_{2}$ /caffeate and now $\mathrm{CO}_{2}$ /isoprene reduction). Being able to utilize a substrate that inhibits a potential competitor could add a third strategy, whereby environments with isoprene present logically favouring acetogenic organisms.

In this study, isoprene was observed to inhibit methanogenesis. The inhibitory effect of isoprene on methanogenesis in sediment slurries has been observed previously [74] where isoprene $(3.6 \mathrm{mM}$ in liquid phase) partially inhibited methanogenesis. Little is known about isoprene concentrations in anaerobic environments and hence it cannot be concluded yet if isoprene mediated inhibition of methanogenesis is ecologically or biogeochemically relevant. Therefore, it is also not yet clear whether isoprene reducers can consume atmospheric isoprene or if they consume isoprene generated in soil sources such as bacteria [20]. Isoprene concentrations used in this and other studies on isoprene biotransformation are in the order of $10^{6}$ times higher than observed under natural conditions $[9,30,34$, 75-77]. Regardless, even at high concentrations the observed capacity for microbes to consume isoprene is far from saturated, suggesting the isoprene consuming microbial community is large relative to the isoprene supply and/ or enzymes involved are highly efficient [75].

\section{Conclusion}

This study explored the anaerobic metabolism of isoprene, which is quantitatively the most abundant volatile hydrocarbon emitted by plants. Isoprene was shown to act as an electron acceptor for homoacetogenic bacteria belonging to the Acetobacterium genera and was shown to be reduced to three different methylbutene isomers in an $\mathrm{H}_{2}$ dependent manner. Isoprene had an inhibitory effect on methanogenesis so there may be a relationship between isoprene emission and methane biosynthesis. The discovery of biohydrogenation of this unsubstituted, unsaturated alkene 
whose functional group makes up $60 \%$ of all Natural Products (isoprenoids or terpenoids) on Earth [78] warrants further investigation. Future experiments should explore the isoprene reduction mechanism, the enzymes involved and its ecological role in biogenic methane sources. Overall, this research demonstrates that isoprene is capable of being reduced in anaerobic environments, implicating a potential previously undiscovered isoprene sink.

Acknowledgements We thank Achim Mall for critically reading the manuscript. We thank Onder Kimyon for technical advice in the laboratory.

\section{Compliance with ethical standards}

Conflict of interest The authors declare that they have no conflict of interest.

Publisher's note: Springer Nature remains neutral with regard to jurisdictional claims in published maps and institutional affiliations.

Open Access This article is licensed under a Creative Commons Attribution 4.0 International License, which permits use, sharing, adaptation, distribution and reproduction in any medium or format, as long as you give appropriate credit to the original author(s) and the source, provide a link to the Creative Commons license, and indicate if changes were made. The images or other third party material in this article are included in the article's Creative Commons license, unless indicated otherwise in a credit line to the material. If material is not included in the article's Creative Commons license and your intended use is not permitted by statutory regulation or exceeds the permitted use, you will need to obtain permission directly from the copyright holder. To view a copy of this license, visit http://creativecommons. org/licenses/by/4.0/.

\section{References}

1. Kesselmeier J, Staudt M. Biogenic volatile organic compounds (VOC): An overview on emission, physiology and ecology. J Atmos Chem. 1999;33:23-88.

2. Atkinson R, Arey J. Gas-phase tropospheric chemistry of biogenic volatile organic compounds: A review. Atmos Environ. 2003;37:197-219.

3. Sanadze GA. Biogenic isoprene (a review). Russ J Plant Physiol. 2004;51:729-41.

4. Laothawornkitkul J, Taylor JE, Paul ND, Hewitt CN. Biogenic volatile organic compounds in the Earth system: Tansley review. New Phytol. 2009;183:27-51.

5. Guenther A, Nicholas C, Fall R, Klinger L, Mckay WA, Scholes $\mathrm{B}$, et al. A global model of natural volatile organic compound emissions. J Geophys Res. 1995;100:8873-92.

6. Arneth A, Schurgers G, Lathiere J, Duhl T, Beerling DJ, Hewitt $\mathrm{CN}$, et al. Global terrestrial isoprene emission models: Sensitivity to variability in climate and vegetation. Atmos Chem Phys. 2011;11:8037-52.

7. Guenther A, Karl T, Harley P, Wiedinmyer C, Palmer PI, Geron C. Estimates of global terrestrial isoprene emissions using MEGAN (model of emissions of gases and aerosols from nature). Atmos Chem Phys Discuss. 2006;6:107-73.

8. Guenther A, Jiang X, Heald CL, Sakulyanontvittaya T, Duhl T, Emmons LK, et al. The model of emissions of gases and aerosols from nature version 2.1 (MEGAN2.1): An extended and updated framework for modeling biogenic emissions. Geosci Model Dev. 2012;5:1471-92.

9. Alvarez LA, Exton DA, Timmis KN, Suggett DJ, McGenity TJ. Characterization of marine isoprene-degrading communities. Environ Microbiol. 2009;11:3280-91.

10. Kirschke S, Bousquet P, Ciais P, Saunois M, Canadell JG, Dlugokencky EJ, et al. Three decades of global methane sources and sinks. Nat Geosci. 2013;6:813-23.

11. Sharkey TD, Monson RK. Isoprene research - 60 years later, the biology is still enigmatic. Plant Cell Environ. 2017;40:1671-8.

12. Sharkey TD, Wiberley AE, Donohue AR. Isoprene emission from plants: Why and how. Ann Bot. 2008;101:5-18.

13. Harley PC, Monson RK, Lerdau MT. Ecological and evolutionary aspects of isoprene emission from plants. Oecologia. 1999;118:109-23.

14. He C, Murray F, Lyons T. Monoterpene and isoprene emissions from 15 Eucalyptus species in Australia. Atmos Environ. 2000;34:645-55.

15. Winters AJ, Adams MA, Bleby TM, Rennenberg H, Steigner D, Steinbrecher R, et al. Emissions of isoprene, monoterpene and short-chained carbonyl compounds from Eucalyptus spp. in southern Australia. Atmos Environ. 2009;43:3035-43.

16. Gelmont D, Stein RA, Mead JF. Isoprene- the main hydrocarbon in human breath. Biochem Biophys Res Commun. 1981;99:145660.

17. King J, Koc H, Unterkofler K, Mochalski P, Kupferthaler A, Teschl G, et al. Physiological modeling of isoprene dynamics in exhaled breath. J Theor Biol. 2010;267:626-37.

18. Broadgate WJ, Malin G, Küpper FC, Thompson A, Liss PS. Isoprene and other non-methane hydrocarbons from seaweeds: A source of reactive hydrocarbons to the atmosphere. Mar Chem. 2004;88:61-73.

19. Kuzma J, Nemecek-Marshall M, Pollock WH, Fall R. Bacteria produce the volatile hydrocarbon isoprene. Curr Microbiol. 1995;30:97-103.

20. Fall R, Copley SD. Bacterial sources and sinks of isoprene, a reactive atmospheric hydrocarbon. Environ Microbiol. 2000;2:123-30.

21. Effmert U, Kalderás J, Warnke R, Piechulla B. Volatile mediated interactions between bacteria and fungi in the soil. J Chem Ecol. 2012;38:665-703.

22. Reeves CE, Penkett S, Bauguitte S, Law KS, Evans MJ, Bandy $\mathrm{BJ}$, et al. Potential for photochemical ozone formation in the troposphere over the North Atlantic as derived from aircraft observations during ACSOE. J Geophys Res D Atmos. 2002;107:1-14.

23. Collins WJ, Derwent RG, Johnson CE, Stevenson DS. The oxidation of organic compounds in the troposphere and their global warming potentials. Clim Change. 2002;52:453-79.

24. Pike RC, Young PJ. How plants can influence tropospheric chemistry: The role of isoprene emissions from the biosphere. Weather. 2009;64:332-6.

25. Krechmer JE, Coggon MM, Massoli P, Nguyen TB, Crounse JD, $\mathrm{Hu} \mathrm{W}$, et al. Formation of low volatility organic compounds and secondary organic aerosol from isoprene hydroxyhydroperoxide low-NO oxidation. Environ Sci Technol. 2015;10:10330-9.

26. Zhao DF, Buchholz A, Tillmann R, Kleist E, Wu C, Rubach F. Environmental conditions regulate the impact of plants on cloud formation. Nat Commun. 2017;8:14067.

27. Engelhart GJ, Moore RH, Nenes A, Pandis SN. Cloud condensation nuclei activity of isoprene secondary organic aerosol. J Geophys Res. 2011;116:1-11.

28. Cleveland CC, Yavitt B. Consumption of atmospheric isoprene in soil. Geophys Res Lett. 1997;24:2379-82.

29. Van Ginkel CG, De Jong E, Tilanus JWR, De Bont JAM. Microbial oxidation of isoprene, a biogenic foliage volatile and of 
1,3-butadiene, an anthropogenic gas. FEMS Microbiol Lett. 1987;45:275-9.

30. Ewers J, Freier-Schröder D, Knackmuss HJ. Selection of trichloroethylene (TCE) degrading bacteria that resist inactivation by TCE. Arch Microbiol. 1990;154:410-3.

31. Van Hylckama Vlieg JET, De Koning W, Janssen DB. Effect of chlorinated ethene conversion on viability and activity of Methylosinus trichosporium OB3b. Appl Environ Microbiol. 1997;63:4961-4.

32. Van Hylckama Vlieg JE, Kingma J, Kruizinga W, Janssen DB. Purification of a glutathione S-transferase and a glutathione conjugate-specific dehydrogenase involved in isoprene metabolism in Rhodococcus sp. strain AD45. J Bacteriol. 1999;181:2094-101.

33. Van Hylckama Vlieg JET, Leemhuis H, Jeffrey H, Spelberg L, Janssen DB. Characterization of the gene cluster involved in isoprene metabolism in Rhodococcus sp. strain AD45. J Bacteriol. 2000;187:1956-63.

34. Crombie AT, El Khawand M, Rhodius VA, Fengler KA, Miller MC, Whited GM, et al. Regulation of plasmid-encoded isoprene metabolism in Rhodococcus, a representative of an important link in the global isoprene cycle. Environ Microbiol. 2015;17:331429.

35. El Khawand M, Crombie AT, Johnston A, Vavlline DV, McAuliffe JC, Latone JA, et al. Isolation of isoprene degrading bacteria from soils, development of isoA gene probes and identification of the active isoprene-degrading soil community using DNA-stable isotope probing. Environ Microbiol. 2016;18:2743-53.

36. Sander R. Compilation of Henry's law constants, version 3.99. Atmos Chem Phys Discuss. 2014;14:29615-30521.

37. Urakawa H, Martens-Habbena W, Stahl DA. High abundance of ammonia-oxidizing archaea in coastal waters, determined using a modified DNA extraction method. Appl Environ Microbiol. 2010;76:2129-35.

38. Engelbrektson A, Kunin V, Wrighton KC, Zvenigorodsky N, Chen F, Ochman H, et al. Experimental factors affecting PCRbased estimates of microbial species richness and evenness. ISME J. 2010;4:642-7.

39. Caporaso JG, Kuczynski J, Stombaugh J, Bittinger K, Bushman FD, Costello EK, et al. Correspondence QIIME allows analysis of high- throughput community sequencing data Intensity normalization improves color calling in SOLiD sequencing. Nat Methods. 2010;7:335-6.

40. Callahan BJ, McMurdie PJ, Rosen MJ, Han AW, Johnson AJA, Holmes SP. DADA2: High-resolution sample inference from Illumina amplicon data. Nat Methods. 2016;13:581-3.

41. Wang Q, Garrity GM, Tiedje JM, Cole JR. Naïve Bayesian classifier for rapid assignment of rRNA sequences into the new bacterial taxonomy. Appl Environ Microbiol. 2007;73:5261-7.

42. DeSantis TZ, Hugenholtz P, Larsen N, Rojas M, Brodie EL, Keller K, et al. Greengenes, a chimera-checked 16S rRNA gene database and workbench compatible with ARB. Appl Environ Microbiol. 2006;72:5069-72.

43. Duhamel M, Edwards EA. Microbial composition of chlorinated ethene-degrading cultures dominated by Dehalococcoides. FEMS Microbiol Ecol. 2006;58:538-49.

44. Ding C, Chow WL, He J. Isolation of Acetobacterium sp. strain $\mathrm{AG}$, which reductively debrominates octa- and pentabrominated diphenyl ether technical mixtures. Appl Environ Microbiol. 2013;79:1110-7.

45. Dolfing J, Janssen DB. Estimation of Gibbs free energies of formation of chlorinated aliphatic compounds. Biodegradation. 1994;5:21-8.

46. Thauer RK, Jungermann K, Decker K. Energy conservation in chemotrophic anaerobic bacteria. Bacteriol Rev. 1977;41: $100-80$.
47. Dean JA. Lange's handbook of chemistry. 15th ed. 2005. New York, N.Y.: McGraw-Hill; 1999. p. 577.

48. Ljungdahl LG, Wood HG. Total synthesis of acetate from $\mathrm{CO} 2$ by heterotrophic bacteria. Annu Rev Microbiol. 1969;23:515-38.

49. Müller V. Energy conservation in acetogenic. Appl Environ Microbiol. 2003;69:6345-53.

50. Drake HL, Küsel KMC. Acetogenic prokaryotes. The prokaryotes: Prokaryotic physiology and biochemistry. Berlin, Heidelberg: Springer; 2013. p. 1-60.

51. Diekert G, Wohlfarth G. Metabolism of homoacetogens. Antonie Van Leeuwenhoek. 1994;66:209-21.

52. Bache R, Pfennig N. Selective isolation of Acetobacterium woodii on methoxylated aromatic acids and determination of growth yields. Arch Microbiol. 1981;130:255-61.

53. Dorn M, Andreesen JR, Gottschalk G. Fumarate reductase of Clostridium formicoaceticum. Arch Microbiol. 1978;119:7-11.

54. Seifritz C, Daniel SL, Gossner A, Drake HL. Nitrate as a preferred electron sink for the acetogen Clostridium thermoaceticum. J Bacteriol. 1993;175:8008-13.

55. Terzenbach DP, Blaut M. Transformation of tetrachloroethylene to trichloroethylene by homoacetogenic bacteria. FEMS Microbiol Lett. 1994;123:213-8.

56. Dilling S, Imkamp F, Schmidt S, Müller V. Regulation of caffeate respiration in the acetogenic bacterium Acetobacterium woodii. Appl Environ Microbiol. 2007;73:3630-36.

57. Hess V, González JM, Parthasarathy A, Buckel W, Müller V. Caffeate respiration in the acetogenic bacterium Acetobacterium woodii: A coenzyme a loop saves energy for caffeate activation. Appl Environ Microbiol. 2013;79:1942-7.

58. Hansen B, Bokranz M, Schönheit P, Kröger A. ATP formation coupled to caffeate reduction by $\mathrm{H} 2$ in Acetobacterium woodii NZva16. Arch Microbiol. 1988;150:447-51.

59. Tschech A, Pfennig N. Growth yield increase linked to caffeate reduction in Acetobacterium woodii. Arch Microbiol. 1984;137:163-7.

60. Willems A, Collins MD. Phylogenetic relationships of the genera Acetobacterium and Eubacterium sensu stricto and reclassification of Eubacterium alactolyticum as Pseudoramibacter alactolyticus gen. nov., comb. nov. Int J Syst Bacteriol. 1996;46:1083-7.

61. Willems A. The Family Comamonadaceae. In: Rosenberg E, DeLong EF, Lory S, Stackebrandt ETF, editors. The Prokaryotes. Berlin, Heidelberg: Springer; 2014. p. 777-851.

62. Daniel SL, Hsu T, Dean SI, Drake HL. Characterization of the H2. and CO-dependent chemolithotrophic potentials of the acetogens Clostridium thermoaceticum and Acetogenium kivui. J Bacteriol. 1990;172:4464-71.

63. Imkamp F, Müller V. Chemiosmotic energy conservation with $\mathrm{Na}^{+}$as the coupling ion during hydrogen-dependent caffeate reduction by Acetobacterium woodii. J Bacteriol. 2002;184: 1947-51.

64. Schuchmann K, Müller V. Autotrophy at the thermodynamic limit of life: A model for energy conservation in acetogenic bacteria. Nat Rev Microbiol. 2014;12:809-21.

65. Prosen EJ, Rossini FD. Heats of formation, hydrogenation, and combustion of the monoolefin hydrocarbons through the hexenes, and of the higher 1-alkenes, in the gaseous state at $25^{\circ} \mathrm{C}$. J Res Natl Bur Stand. 1946;36:269-75.

66. De Bruin WP, Kotterman MJJ, Posthumus MA, Schraa G, Zehnder AJB. Complete biological reductive transformation of tetrachloroethene to ethane. Appl Environ Microbiol. 1992;58:1996-2000.

67. Koene-Cottaar FHM, Schraa G. Anaerobic reduction of ethene to ethane in an enrichment culture. FEMS Microbiol Ecol. 1998;25:251-6.

68. Mundle SOC, Johnson T, Lacrampe-Couloume G, Perez-de-Mora A, Edwards EA, Mcmaster M, et al. Monitoring biodegradation of 
ethene and bioremediation of chlorinated ethenes at a contaminated site using CSIA. Environ Sci Technol. 2012;46:1731-8.

69. Elsgaard L. Reductive transformation and inhibitory effect of ethylene under methanogenic conditions in peat-soil. Soil Biol Biochem. 2013;60:19-22.

70. Lever MA. Acetogenesis in the energy-starved deep biosphere-a paradox? Front Microbiol. 2012;2:1-18.

71. Avery GB, Shannon RD, White JR, Martens CS, Alperin MJ. Controls on methane production in a tidal freshwater estuary and a peatland: Methane production via acetate fermentation and $\mathrm{CO} 2$ reduction. Biogeochemistry. 2003;62:19-37.

72. Drake HL, Daniel SL, Küsel K, Matthies C, Kuhner C, BrausStromeyer S. Acetogenic bacteria: what are the in situ consequences of their diverse metabolic versatilities? BioFactors. 1997;6:13-24.

73. Drake HL, Gößner AS, Daniel SL. Old acetogens, new light. Ann N Y Acad Sci. 2008;1125:100-28.
74. Schink B. Inhibition of methanogenesis by ethylene and other unsaturated hydrocarbons. FEMS Microbiol Lett. 1985;31:63-8.

75. Gray CM, Helmig D, Fierer N. Bacteria and fungi associated with isoprene consumption in soil. Elem Sci Anthr. 2015;3:000053.

76. Cleveland CC, Yavitt JB. Microbial consumption of atmospheric isoprene in a temperate forest soil microbial consumption of atmospheric isoprene in a temperate forest soil. Appl Environ Microbiol. 1998;64:172-7.

77. Van Hylckama Vlieg JE, Kingma J, Van den Wijngaard AJ, Janssen DB. A glutathione S-transferase with activity towards cis1, 2-dichloroepoxyethane is involved in isoprene utilization by Rhodococcus sp. strain AD45. Appl Environ Microbiol. 1998;64:2800-5.

78. Firn R. The main classes of NPs-Only a few pathways lead to the majority of NPs. Nature's Chemicals. Oxford: Oxford University Press; 2009. p. 1-25. 